\title{
IMPLEMENTASI PEMBELAJARAN BIOLOGI BERBASIS DARING PADA MASA PANDEMI COVID-19 DI MADRASAH ALIYAH NEGERI
}

\author{
Ismi Fahrunnisah Rambe ${ }^{{ }^{*}}$, Indayana Febriani Tanjung1 \\ ${ }^{1}$ Universitas Islam Negeri Sumatera Utara \\ *fahrunnisahrambe@gmail.com
}

\begin{abstract}
ABSTRAK
Penelitian ini bertujuan untuk mendeskripsikan perencanaan, pelaksanaan, dan penilaian dari implementasi pembelajaran biologi berbasis daring pada masa pandemi COVID-19 di Madrasah Aliyah Negeri. Penelitian ini merupakan penelitian kualitatif dengan metode dekskriptif. Teknik sampling yang digunakan yaitu purposive sampling dengan instrumen pengumpulan data diperoleh dari observasi, wawancara, dan studi dokumentasi. Analisis data yang dilakukan yaitu reduksi data, penyajian data, dan penarikan kesimpulan. Penelitian ini dilaksanakan dari JuliSeptember 2020 dengan subjek penelitian yaitu kepala sekolah, guru biologi, siswa. Berdasarkan analisis data diketahui hasil penelitian bahwa implementasi pembelajaran biologi meliputi 3 proses yaitu perencanaan, pelaksanaan, dan penilaian. Perencanaan berupa pendataan kondisi dan nomor telepon siswa lalu membuat grup WhatsApp, menyiapkan rancangan perencanaan pembelajaran (RPP), menyiapkan bahan materi, menentukan media pembelajaran. Pelaksanaan yaitu kegiatan pendahuluan, kegiatan inti, dan kegiatan penutup pembelajaran. 1) Kegiatan pendahuluan berupa mengisi absensi melalui google form dan penyampaian tujuan pembelajaran pada google classroom, 2) kegiatan inti berupa penyampaian materi, sesi tanya jawab dan diskusi, 3) kegiatan penutup berupa penarikan kesimpulan dan penugasan. Penilaian yang dilakukan berupa penilaian pengetahuan dan penilaian keterampilan. 1) Penilaian pengetahuan dilihat dari hasil tes pilihan ganda/uraian, diskusi tanya jawab dan percakapan serta penugasan, 2) Penilaian keterampilan dilihat dari hasil penugasan proyek, produk, dan penilaian portofolio. Pembelajaran biologi berbasis daring menjadikan kegiatan pembelajaran tetap dapat dilaksanakan pada masa pandemi COVID-19.
\end{abstract}

Kata Kunci: Pandemi COVID-19, Pembelajaran Biologi, Pembelajaran Daring

\begin{abstract}
This research aims to describe the planning, implementation, and assessment of the implementation of online-based biology learning during the COVID-19 pandemic at Madrasah Aliyah Negeri. This research is a qualitative research with a descriptive method. The sampling technique used is purposive sampling with data collection instruments obtained from observation, interviews, and documentation studies. Data analysis was carried out, namely data reduction, data presentation, and drawing conclusions. This research was conducted from JulySeptember 2020 with the research subjects, namely the principal, biology teacher, and students. Based on data analysis, it was known that the implementation of biology learning includes 3 processes, namely planning, implementing, and assessing. Planning in the form of data collection on student conditions and telephone numbers then creating WhatsApp groups, preparing lesson planning plans (RPP), preparing material, determining learning media. Implementation namely preliminary, core, and closing learning activities. 1) Preliminary activities: filling in attendance via google form and submitting learning objectives to google classroom, 2) core activities: delivering material, question and answer sessions and discussions, 3) closing activities: drawing conclusions and assignments. Assessment, namely knowledge assessment and skills assessment. 1) Assessment of knowledge is seen from the results of multiple choice tests / descriptions, question and answer discussions and conversations as well as assignments, 2) Skills assessment is seen from the results of project assignments, products and portfolio assessments.
\end{abstract}

Keywords: COVID-19 Pandemic, Biology Learning, Online Learning 


\section{PENDAHULUAN}

Pada akhir tahun 2019, dunia dihadapkan pada persoalan munculnya dan menyebarnya wabah virus corona. Wabah yang muncul di kota Wuhan ini, pertama kali dilaporkan oleh China kepada WHO (World Health Organization) pada tanggal 31 Desember 2019. Coronavirus merupakan jenis penyakit baru yang ditemukan pada tahun 2019 dan belum pernah diidentifikasi menyerang manusia sebelumnya. Karena penyebaran COVID-19 yang sangat cepat, WHO (World Health Organization) menetapkan virus corona sebagai pandemi pada tanggal 11 Maret 2020. Kemudian, Direktur Jenderal WHO pada 30 Januari 2020 di Jenewa menetapkan situasi ini sebagai Public Health Emergency of International Concern (PHEIC), dengan menyatakan peringatan untuk semua negara agar mewaspadai penyebaran COVID-19 di wilayah negara manapun. WHO (2020) merekomendasi bahwa menjaga jarak dapat mencegah penularan COVID-19. Dampaknya yaitu pembelajaran dilakukan dari rumah masing-masing (study from home) (Handarini \& Wulandari, 2020).

Berdasarkan penetapan PHEIC maka dikeluarkan Keputusan Presiden Nomor 11 Tahun 2020 tentang Penetapan Kedaruratan Kesehatan Masyarakat terkait COVID-19 dan Peraturan Pemerintah Nomor 21 Tahun 2020 tentang PSBB (Pembatasan Sosial Berskala Besar) dalam Rangka Percepatan Penanganan COVID-19 (PP No. 21 Tahun 2020). Penetapan PSBB berupa "peliburan sekolah dan tempat kerja serta pembatasan kegiatan keagamaan" harus tetap mempertimbangkan kebutuhan pendidikan, produktivitas kerja, dan ibadah penduduk. Sementara untuk PSBB berupa "pembatasan kegiatan di tempat atau fasilitas umum" harus memperhatikan pemenuhan kebutuhan dasar penduduk". Melalui hal ini aktivitas yang melibatkan kumpulan orangorang, kini mulai dibatasi dan dihimbau untuk bekerja, belajar, dan beribadah dari rumah untuk menekan angka pasien yang terpapar COVID-19.
Dalam penetapan PSBB yang dilaksanakan, pada tanggal 24 Maret 2020 Menteri Pendidikan dan Kebudayaan Republik Indonesia mengeluarkan Surat Edaran Nomor 4 Tahun 2020 Tentang Pelaksanaan Kebijakan Pendidikan dalam Masa Darurat Penyebaran COVID-19, dalam Surat Edaran tersebut dijelaskan bahwa proses belajar dilaksanakan di rumah melalui pembelajaran daring (dalam jaringan) atau jarak jauh dilaksanakan untuk memberikan pengalaman belajar yang bermakna bagi siswa.

Menyikapi Surat Edaran Menteri Pendidikan dan Kebudayaan tersebut maka Bupati Mandailing Natal mengeluarkan Surat Edaran Bupati Mandailing Natal Nomor 420/1485/DISDIK/2020 tanggal 28 Mei 2020 yang awalnya sebagai tanggapan terhadap COVID-19 yaitu pembelajaran mandiri di rumah selama 14 hari diperpanjang dengan jangka waktu perpanjang disesuaikan sampai daerah Mandailing Natal bebas dari infeksi COVID-19.

Melalui surat edaran tanggapan terhadap pandemi COVID-19, maka semua proses pembelajaran pada mata pelajaran apapun dilaksanakan di rumah melalui pembelajaran daring/jarak jauh. Pembelajaran secara daring telah menjadi tuntutan dunia pendidikan sejak beberapa tahun terakhir $\mathrm{He}, \mathrm{Xu}$, \& Kruck, 2014). Begitupun dalam mata pelajaran biologi. Pembelajaran biologi yang biasanya dilaksanakan di kelas dengan interaksi langsung yang pada umumnya membutuhkan penjelasan dan praktik langsung dengan lingkungan alam berubah menjadi pembelajaran berbasis daring dengan guru tetap memperhatikan kondisi masing-masing siswa dan kesenjangan akses/fasilitas di rumah, sehingga guru bisa memilih berbagai jenis cara dan aplikasi sebagai sarana penghubung atau akses guru dengan siswa dalam proses pembelajaran di rumah, dan tentunya gurulah yang mengelola bagaimana proses pembelajaran daring tersebut dilaksanakan. Beragam platform media pembelajaran dapat digunakan dalam mendukung pelaksanaan pembelajaran daring, 
seprti google classroom, edmodo, schoology (Enriquez, 2014; Sicat, 2015; Iftakhar, 2016), dan whatsApp (So, 2016).

Dalam pembelajaran daring ini tentunya banyak persiapan dan proses yang berbeda dari kegiatan belajar biasanya dilakukan, sehingga guru maupun siswa harus bisa beradaptasi dan mampu melaksanakan kegiatan belajar daring dengan benar supaya tujuan pembelajaran dapat tercapai (Syahmina et al., 2020). Guru sebagai pengajar harus mampu dan mengerti bagaimana sistem kegiatan belajar secara daring ini dilaksanakan sehingga siswa dapat melaksanakan kegiatan belajar dan memahami meteri pembelajaran dengan baik. Oleh karena itu, guru memiliki peran yang sangat penting dalam proses pelaksanaan pembelajaran daring.

Guru sebagai pengelola pembelajaran secara daring harus mampu mempersiapkan bagaimana pembelajaran daring akan dilakukan meskipun guru tersebut belum pernah melakukan pembelajaran berbasis daring bahkan ada beberapa guru yang baru mendengar istilah pembelajaran berbasis daring pertama kalinya. Hal ini dapat diketahui peneliti setelah melakukan observasi di daerah penelti yang sudah terjangkit penyebaran COVID-19 sehingga telah ditutupnya sekolah dan diterapkannya pembelajaran jarak jauh untuk pencegahan penyebaran COVID-19. Guruguru di MAN 1 Mandailing Natal belum pernah melaksanakan pembelajaran berbasis daring dan bahkan pembelajaran daring merupakan salah satu hal yang baru bagi pihak sekolah, tidak terkecuali pada mata pelajaran biologi yang umumnya memerlukan media lingkungan alam dan penjelasan secara langsung dalam pembelajarannya. Sehingga, bagaimana perencanaan, pelaksanaan, dan penilaian dalam pembelajaran biologi berbasis daring belum memiliki acuan bagi guru biologi karena belum pernah dilaksanakan.

Berdasarkan pemaparan di atas, peneliti menemukan permasalahan tentang bagaimana proses pembelajaran daring dilaksanakan oleh sekolah dan guru yang belum pernah tahu dan belum pernah melaksanakan pembelajaran daring sehingga peneliti melakukan penelitian mengenai implementasi pembelajaran biologi berbasis daring pada masa pandemi COVID-19 di MAN 1 Mandailing Natal dengan tujuan untuk mendeskripsikan perencanaan, pelaksanaan, dan penilaian pembelajaran biologi berbasis daring.

\section{METODE}

Penelitian ini merupakan penelitian kualitatif dengan metode deskriptif (Sugiyono, 2017). Penelitian ini mendeskripsikan implementasi pembelajaran biologi berbasis daring pada masa pandemi COVID-19 di MAN 1 Mandailing Natal. Teknik sampling yang digunakan adalah purposive sampling. Subjek penelitian ini adalah Kepala sekolah, guru biologi, dan siswa MAN 1 Mandailing Natal. Analisis data yang dilakukan yaitu reduksi data, penyajian data, dan penarikan kesimpulan.

Instrumen pengumpulan data diperoleh dari hasil wawancara, observasi, dan studi dokumentasi. Pertanyaan wawancara dan observasi, serta studi dokumentasi dibuat berdasarkan pedoman yang telah ditetapkan dan telah dilakukan validasi. 1) Jenis wawancara yang digunakan dalam penelitian ini adalah wawancara terencana tidak terstruktur, yaitu pewawancara menyusun rencana dan menyiapkan materi tetapi tidak terinci menurut format tertentu. Sumber wawancara peneliti yaitu kepala sekolah, guru biologi, dan siswa kelas XII di MAN 1 Mandailing Natal. 2) Jenis observasi yang digunakan dalam penelitian ini adalah observasi partisipatif pasif atau nonpartisipatif, yaitu peneliti datang di tempat kegiatan orang yang diamati, tetapi tidak ikut terlibat dalam kegiatan tersebut. Dalam hal ini peneliti mengikuti dan melakukan pengamatan kegiatan pembelajaran biologi berbasis daring oleh guru biologi dan siswa MAN 1 Mandailing Natal. 3) Studi dokumentasi merupakan pelengkap dari penggunaan metode observasi dan wawancara dalam penelitian kualitatif. Pengumpulan data studi dokumentasi yaitu berupa gambar proses pembelajaran daring dan 
Ismi Fahrunnisah Rambe \& Indayana Febriani Tanjung, Implementasi Pembelajaran Biologi Berbasis Daring pada Masa Pandemi COVID-19 di Madrasah Aliyah Negeri.

Jurnal Biolokus: Jurnal Penelitian Pendidikan Biologi dan Biologi Vol.4(1)

data-data pembelajaran daring di MAN 1 implementasi yaitu tahap perencanaan, tahap Mandailing Natal.

Pedoman yang diamati dalam pelaksanaan, dan tahap penilaian (Syaifuddin, pengumpulan data melalui wawancara, 2016). Pedoman pengumpulan data melalui observasi, dan studi dokumentasi didasarkan wawancara, observasi, dan studi dokumentasi dapat dilihat pada Tabel 1.

pada tahapan atau langkah dalam proses

Tabel 1. Aspek-aspek pengamatan

\begin{tabular}{ll}
\hline No & \multicolumn{1}{c}{ Aspek yang Diamati } \\
\hline 1 & $\begin{array}{l}\text { Perencanaan Pembelajaran } \\
\text { Menentukan aplikasi interaksi yang dipakai dalam penyampaian pembelajaran melalui daring } \\
\text { Menyiapkan alat dan bahan pendukung pembelajaran berbasis daring }\end{array}$ \\
$\mathbf{2}$ & $\begin{array}{l}\text { Menyiapkan rencana pelaksanaan pembelajaran berbasis daring } \\
\text { Pelaksanaan Pembelajaran }\end{array}$ \\
& $\begin{array}{l}\text { Melaksanakan kegiatan pendahuluan pembelajaran } \\
\text { Melaksanakan kegiatan inti pembelajaran }\end{array}$ \\
& $\begin{array}{l}\text { Melaksanakan kegiatan penutup pembelajaran } \\
\text { Penilaian Pembelajaran }\end{array}$ \\
& $\begin{array}{l}\text { Menentukan bentuk/aspek dalam penilaian } \\
\text { Menentukan bentuk penugasan secara daring }\end{array}$ \\
\hline
\end{tabular}

Tabel 2. Kisi-kisi lembar observasi

\begin{tabular}{|c|c|c|}
\hline No & Indikator & Deskriptor \\
\hline 1 & $\begin{array}{l}\text { Respon positif terhadap } \\
\text { bahan ajar (aplikasi atau } \\
\text { media interaksi daring } \\
\text { yang digunakan) }\end{array}$ & $\begin{array}{l}\text { - Siswa paham dan mampu menggunakan bahan ajar yang digunakan } \\
\text { - Memperhatikan bahan ajar yang digunakan dengan seksama } \\
\text { - Tidak melakukan kegiatan-kegiatan di luar kegiatan belajar }\end{array}$ \\
\hline 2 & $\begin{array}{l}\text { Bahan ajar yang } \\
\text { membuat siswa tertarik } \\
\text { belajar }\end{array}$ & $\begin{array}{l}\text { - Siswa memperhatikan dengan seksama materi yang ditampilkan } \\
\text { - Siswa mengeluh karena materi yang ditampilkan membingungkan }\end{array}$ \\
\hline 3 & $\begin{array}{l}\text { Siswa terampil } \\
\text { menggunakan bahan ajar }\end{array}$ & $\begin{array}{l}\text { - Siswa tidak banyak bertanya tentang cara menggunakan bahan ajar } \\
\text { - Siswa mengikuti petunjuk yang ada dalam bahan ajar dengan baik }\end{array}$ \\
\hline 4 & $\begin{array}{l}\text { Rasa mampu dalam } \\
\text { belajar }\end{array}$ & $\begin{array}{l}\text { - Siswa dapat menjawab latihan soal yang diberikan } \\
\text { - Siswa dapat membuat kesimpulan dari materi pada bahan ajar }\end{array}$ \\
\hline
\end{tabular}

\section{HASIL DAN PEMBAHASAN}

Dalam penelitian ini permasalahan yang dibahas dalam penelitian ada tiga aspek yang dibahas dalam penelitian yaitu perencanaan, pelaksanaan, dan penilaian pada pembelajaran biologi berbasis daring di MAN 1 Mandailing Natal. Sebagaimana dalam proses implementasi setidaknya ada tiga tahapan atau langkah yang harus dilaksanakan, yaitu: tahap perencanaan, tahap pelaksanaan, dan tahap penilaian (Majid, 2015; Syaifuddin, 2016).

\section{Perencanaan Implementasi jaran Biologi Berbasis Daring}

Perencanaan dalam

Pembelapenerapan pembelajaran biologi berbasis daring pada masa pandemi COVID-19 di MAN 1 Mandailing
Natal oleh sekolah dilakukan dengan kerja sama antara kepala sekolah, guru-guru, dan siswa. Penetapan sistem pembelajaran secara daring yang mudah dijangkau guru dan siswa yaitu aplikasi yang ditetapkan sekolah dalam pelaksanaan pembelajaran daring adalah google form, google clasroom, dan whatsApp. selanjutnya dilakukan pendataan nomor telepon siswa, pengaturan roster pembelajaran secara daring, mengadakan pengarahan kepada guru-guru yang selanjutnya guru-guru tersebut memberikan pengarahan kepada siswa dalam pelaksanaan pembelajaran daring disesuaikan dengan mata pelajaran yang diajarkan oleh guru tersebut.

Perencanaan pembelajaran biologi berbasis daring pada masa pandemi COVID-19 
oleh guru biologi di MAN 1 Mandailing Natal oleh guru biologi tersebut meliputi membuat grup whatsApp per kelas dan menyiapkan rencana pelaksanaan pembelajaran jarak jauh

Rencana Pelaksanaan Pembelajaran (RPP) yang dibuat oleh guru biologi di MAN 1 Mandailing Natal disesuaikan dengan kondisi dan sarana pembelajaran yang digunakan sehingga guru biologi membuat RPP yang dimuat dalam 1 lembar RPP per materi pembelajaran untuk memudahkan dalam pembelajaran secara daring, hal-hal yang di muat di dalam RPP tersebut yaitu: (1) identitas mata pelajaran, sekolah, semester, materi, kelas, dan alokasi waktu, (2) kompetensi dasar dan indikator pencapaian kompetensi, (3) tujuan pembelajaran, (4) langkah-langkah pembelajaran, dan (5) penilaian hasil pembelajaran

Rencana pelaksanaan pembelajaran (RPP) yang dibuat guru biologi akan dibagikan kepada siswa melalui aplikasi yang digunakan dalam pembelajaran biologi secara daring yaitu google classroom atau whatsApp, yang bertujuan agar siswa dapat mengetahui tujuan dan langkahlangkah pembelajaran yang akan dilaksanakan. Sebelum pelaksanaan pembelajaran biologi berbasis daring, guru telah menyiapkan bahan materi yang akan disampaikan kepada siswa. Materi yang akan disampaikan dibuat dalam bentuk file pdf, ppt, dan video yang bisa dengan mudah diunduh oleh siswa. Media pembelajaran yang digunakan hanya jenis media pembelajaran berupa format teks, video, dan power point.

\section{Pelaksanaan Implementasi Pembelajaran Biologi Berbasis Daring}

Tahapan proses pembelajaran biologi berbasis daring umumnya sama dengan tahapan pada proses pembelajaran bisanya yaitu berupa pendahuluan, isi, penutup. Berikut adalah tahapan dalam proses pembelajaran biologi berbasis daring pada masa pandemi COVID-19 di MAN 1 Mandailing Natal:

\section{Kegiatan Pendahuluan}

Guru membagikan link absensi google form ke grup whatsApp (Gambar 1). Kemudian siswa diarahkan untuk mengisi absensi (Gambar 2).

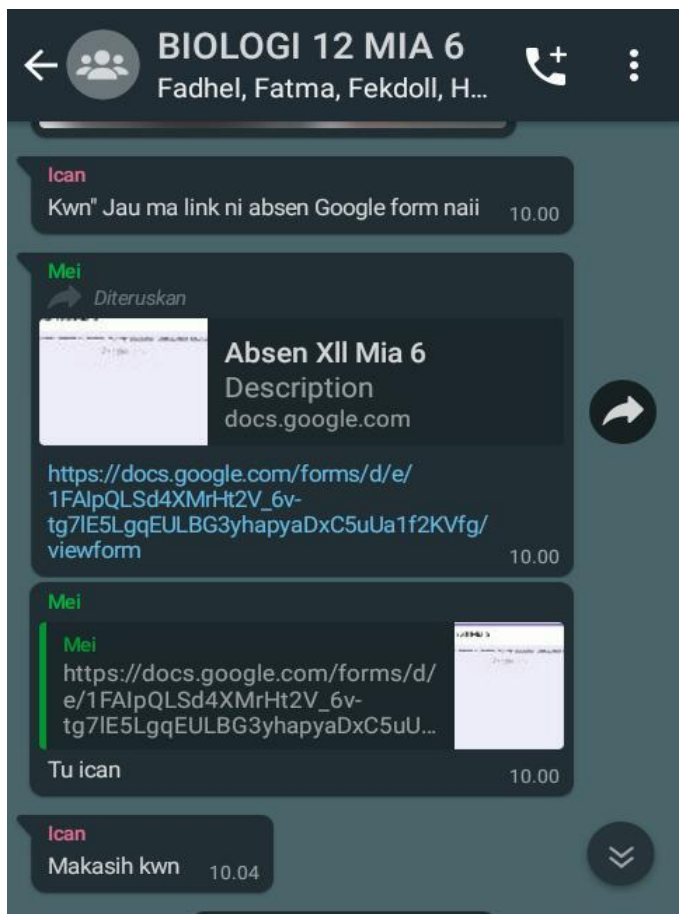

Gambar 1. Tampilan link google form dikirim guru kepada ketua kelas dan langsung ke grup kelas.

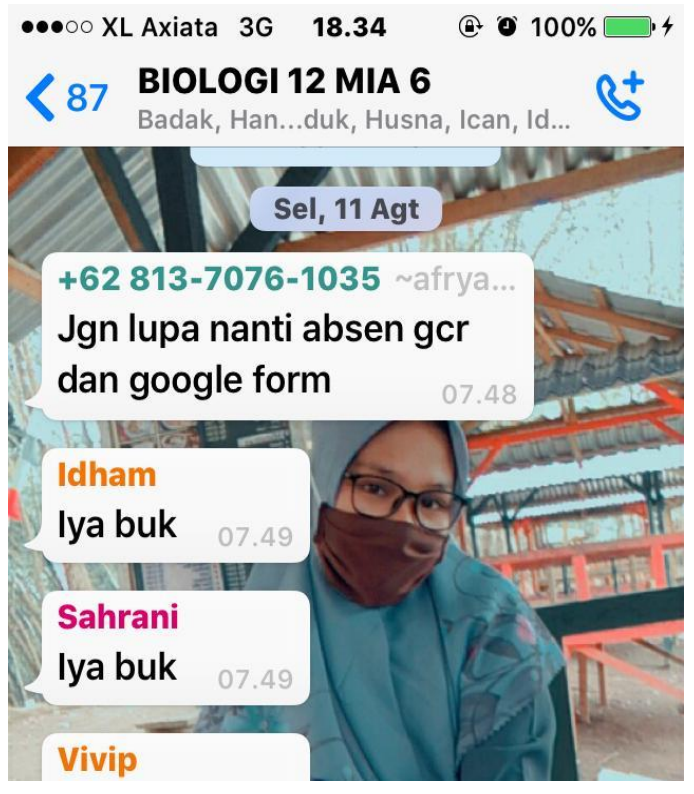

Gambar 2. Tampilan guru mengarahkan siswa mengisi absensi di google form. 
Ismi Fahrunnisah Rambe \& Indayana Febriani Tanjung, Implementasi Pembelajaran Biologi Berbasis Daring pada Masa Pandemi COVID-19 di Madrasah Aliyah Negeri.

\section{Jurnal Biolokus: Jurnal Penelitian Pendidikan Biologi dan Biologi Vol.4(1)}

Pada link absensi di google form, siswa wajib mengisi setiap bagian dari absensi. Pada tampilan absensi (Gambar 3) terdapat beberapa hal yang wajib diisi oleh siswa yaitu: 1) Nama siswa, 2) No. Urut absen, 3) Tanggal (klik tombol disebelah kanan maka akan muncul pilihan tanggal), 4) Kelas (ada pilihan kelas), 5) Keterangan: hadir, sakit, izin, yang lainnya (bisa diisi sendiri), 6) Terakhir klik tombol kirim.

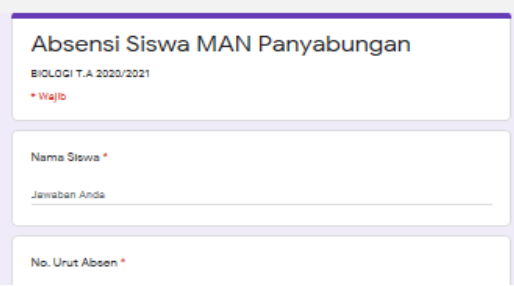

Gambar 3. Tampilan absensi di google form.

Setelah siswa mengklik tombol kirim, maka akan muncul tampilan seperti Gambar 4. Jika waktu absensi yang ditentukan guru telah selesai maka guru bisa melihat hasil pengisian absensi (Gambar 5).

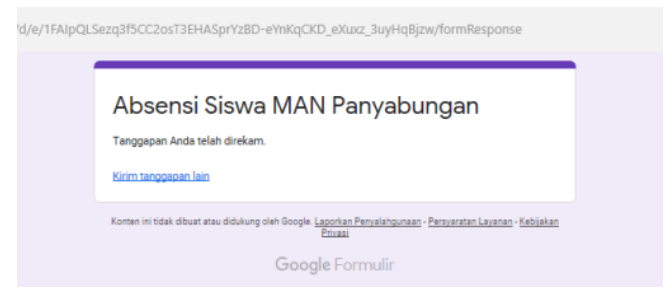

Gambar 4. Tampilan setelah mengisi absensi di google form.
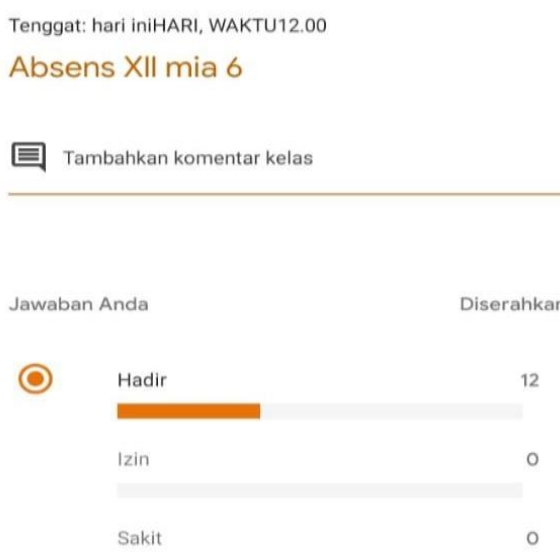

Gambar 5. Tampilan hasil absensi di google form.

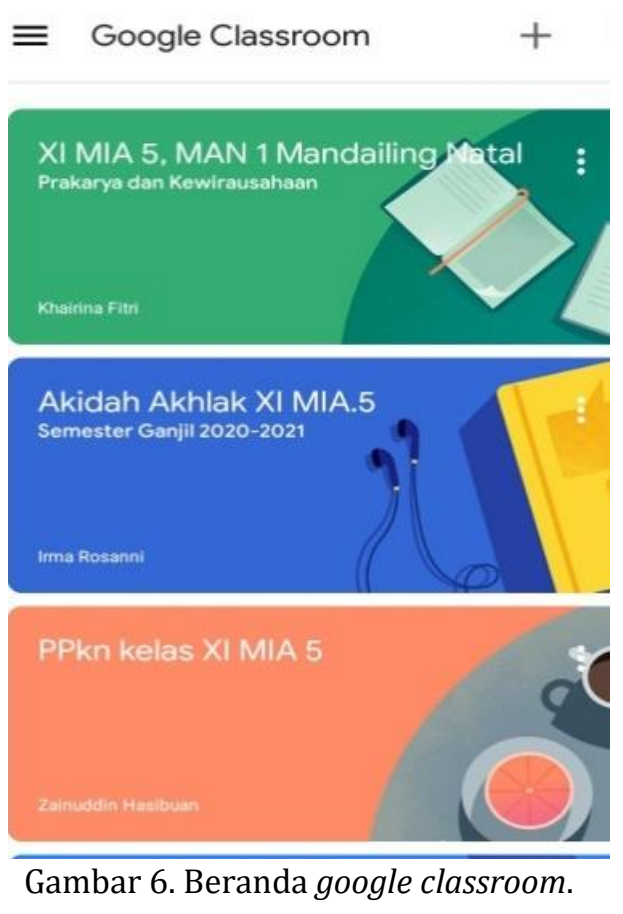

Langkah berikutnya yaitu guru dan siswa masuk ke aplikasi google classroom, lalu guru menyampaikan tujuan pembelajaran (Gambar 6). Untuk mata pelajaran biologi siswa tinggal mengklik pilihan biologi, dan akan muncul tampilan seperti Gambar 7.

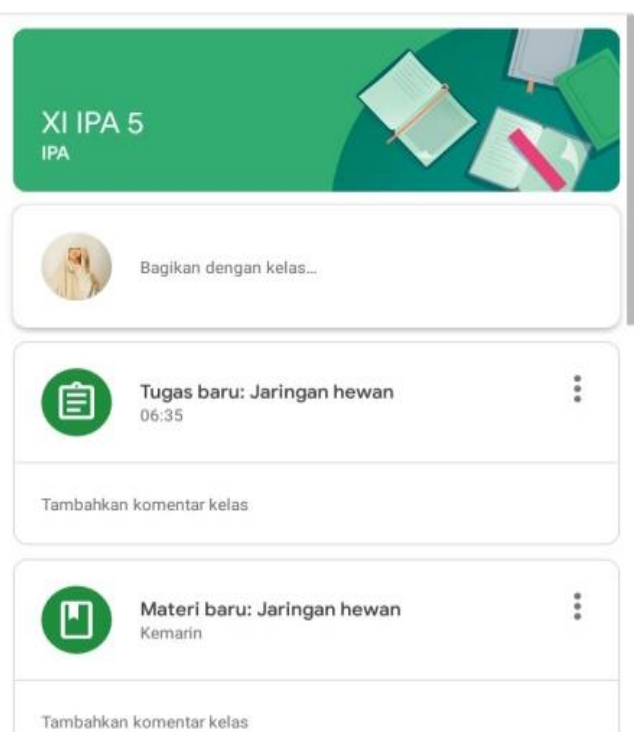

Gambar 7. Tampilan laman kelas setelah laman utama google classroom. 


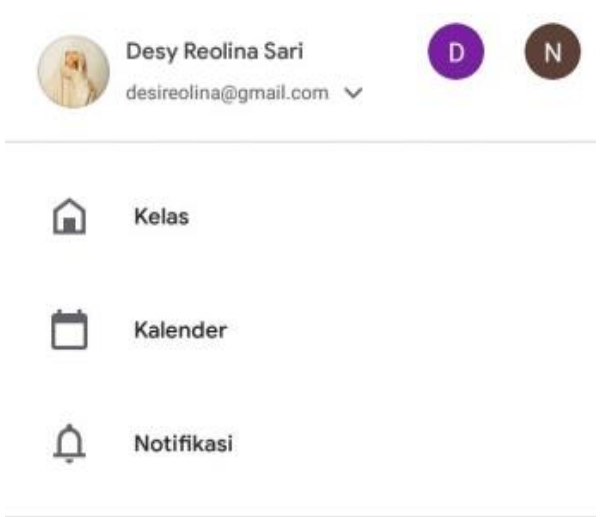

Anda terdaftar di mata pelajaran

国 Daftar tugas

X XIMIA 5, MAN 1 Mandailing Natal

Prakarya dan Kewirausahaan

A Akidah Akhlak XI MIA.5

Sernester Ganjil 2020-2021

P PPkn kelas XI MIA 5

K KIMIA XI MIA 5

SARIKA PERMATA PUTRI, S.Pd

Gambar 8. Tampilan pada laman akun google classroom.

Tiap akun memiliki pilihan item yang dapat dipilih siswa (Gambar 8). Pilihan item folder pada akun google classroom yaitu: kelas, kalender, notifikasi, daftar tugas, folder saya, setelan, bantuan kebijakan privasi, persyaratan layanan.

Selanjutnya pada tampilan utama ada pilihan bagian bawah yaitu forum, tugas kelas, dan anggota pada tampilan google classroom dengan tampilan lama berupa folder terbaru dalam pembelajaran seperti materi, tugas, dan hasil ujian pada Gambar 9.

Melalui forum, guru membahas pembelajaran yang akan dilaksanakan, menyampaikan tujuan, manfaat pembelajaran, langkah-langkah pembelajaran melalui file yang diupload oleh guru.

\section{Kegiatan Inti}

Guru menyampaikan materi pembelajaran yang akan dipelajari. Biasanya guru menjelaskan materi melalui format teks dalam bentuk word, pdf, atau ringkasan, power point, video yang diupload di google classroom, dan siswa diarahkan untuk melihat, membaca, memahami, dan mengamati materi tersebut.

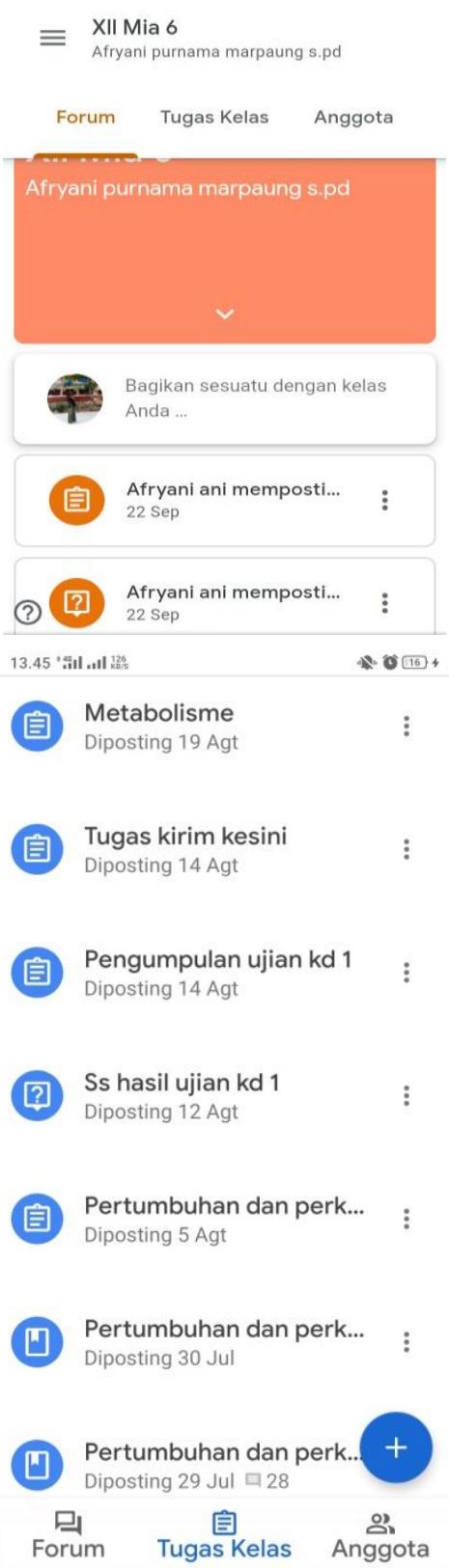

Gambar 9. Tampilan pilihan pada laman google classroom.

Pada akun masing-masing siswa ada bagian notifikasi yang akan memunculkan hal yang baru saja diupload dan dibagikan oleh guru lalu siswa dapat mengklik notifikasi dan akan muncul apa yang dibagikan guru dengan keterangan, seperti media pembelajaran video, gambar, atau file berisi penjelasan materi yang terkadang disertakan dengan penugasan 
Ismi Fahrunnisah Rambe \& Indayana Febriani Tanjung, Implementasi Pembelajaran Biologi Berbasis Daring pada Masa Pandemi COVID-19 di Madrasah Aliyah Negeri.

\section{Jurnal Biolokus: Jurnal Penelitian Pendidikan Biologi dan Biologi Vol.4(1)}

kepada siswa dengan arahan pengiriman tugas serta bagi siswa yang kurang paham bisa berkomentar pada kolom komentar (Gambar 10).

\begin{tabular}{l} 
Petunjuk Tugas Siswa \\
Metabolisme \\
100 poin \\
\hline Tontonlah video berikut dan ringkaslah \\
materi yg ada divideo tersebut. Dan \\
edit dengan foto masing2 nanti kirim \\
di folder ini jangan di wa! \\
Lampiran \\
Metabolisme__Enzim, Struktur, \\
Sifat, Cara Kerja, dan Faktor \\
Jaringan hewan \\
Baca dan pahami \\
20200920_211249.jpg
\end{tabular}

Gambar 10. Tampilan materi dan tugas dari guru di google classroom.

Terkadang guru membagikan materi melalui whatsApp jika ada kendala pada google classroom, seperti pada Gambar 11 dimana guru membagikan materi dalam bentuk power point (ppt) melalui whatsApp.

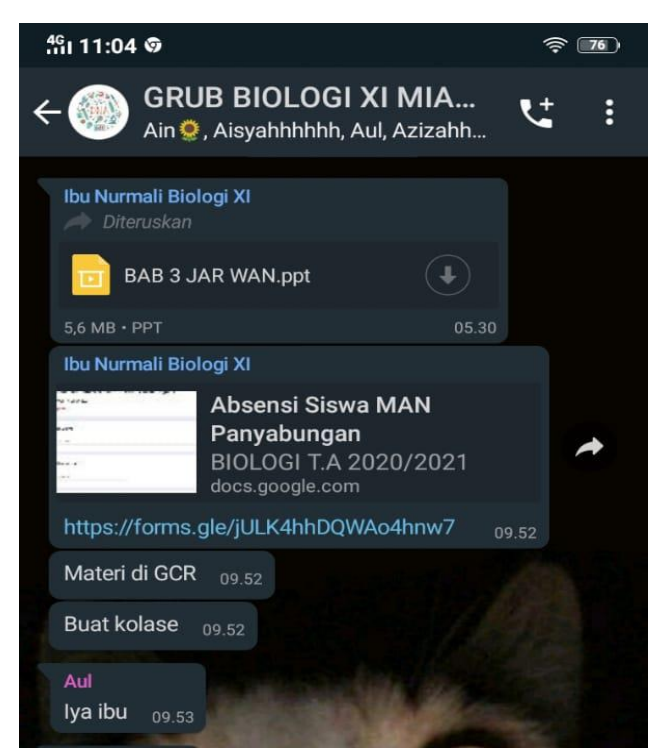

Gambar 11. Tampilan materi dan tugas dari guru di whatsApp.

\section{Pertumbuhan dan perkembangan hewan}

\section{Bacalah kemudian ringkas di buku catatan kirim ke class room hasilnya sesuai folder tugas jangan di forum \\ Biologi Kelas 12 | Pertumbuhan dan Perkembangan pada Hewan}

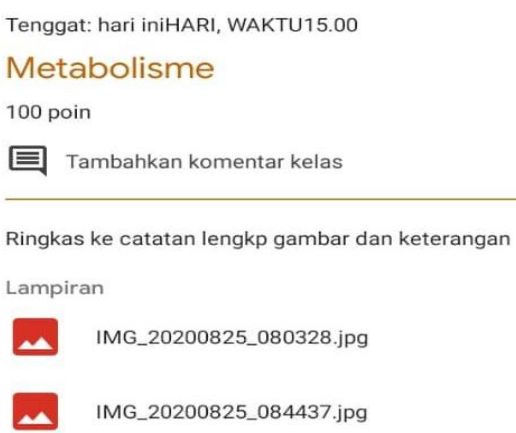

Gambar 12. Tampilan arahan meringkas dari guru di google classroom.

Guru tetap menggunakan buku paket biologi dari sekolah dalam pembelajaran biologi berbasis daring, sehingga terkadang guru menyuruh siswa membaca buku tersebut dan juga memberikan tugas dari buku paket tersebut. Selain itu, guru terkadang membagikan gambar-gambar yang berkaitan dengan materi (Gambar 12).

Selanjutnya, guru memberi kesempatan bertanya terkait dengan materi yang telah disampaikan melalui forum chat atau melalui grup whatsApp. Dalam hal ini, terkadang siswa juga diberikan kesempetan menjawab pertanyaan dari temannya sehingga terjadi diskusi antara siswa.

\section{Kegiatan Penutup}

Guru menyampaiakan kesimpulan keseluruhan dari diskusi tanya jawab dan materi pembelajaran. Pada tahap ini guru lebih sering menyampaikan kesimpulan melalui voice note di grup whatsApp supaya beberapa siswa yang terkendala jaringan pada saat di google classroom tetap dapat mengetahui kesimpulan pembelajaran (Gambar 13). 
Ismi Fahrunnisah Rambe et al., Implementasi Pembelajaran Biologi Berbasis Daring pada Masa

Pandemi Covid-19 di Madrasah Aliyah Negeri.

Jurnal Biolokus: Jurnal Penelitian Pendidikan Biologi dan Biologi Vol.4(1)

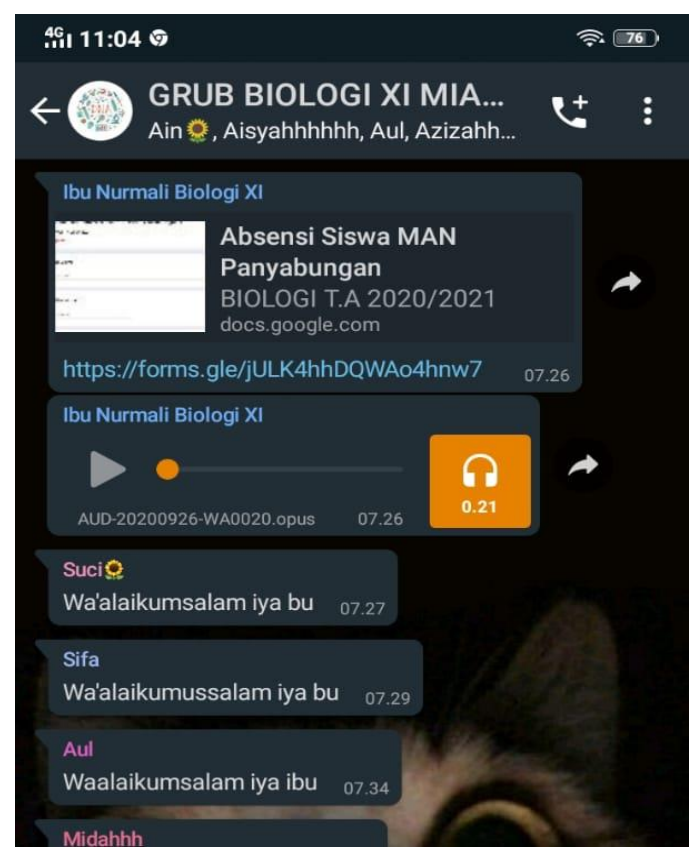

Gambar 13. Tampilan voice note kesimpulan pembelajaran di grup whatsApp dari guru.

Guru membagikan tugas dan menagih tugas sebelumnya jika ada tugas yang harus dikumpulkan. Bentuk tugas yang diberikan guru beragam, yaitu berupa membuat tingkasan materi, membuat gambar yang berkaitan dengan materi, membuat video, menjawab soal. Bentuk tugas disesuaikan guru dengan materi yang dipelajari. Salah satu contoh tampilan dari penugasan dari guru kepada siswa, dimana siswa dapat mendownload file pertanyaan yang telah dilampirkan guru dan mengerjakan sesuai keterangan dari guru dapat dilihat pada Gambar 14.

Guru menyampaikan judul materi pembelajaran untuk pertemuan selanjutnya. Mengenai tugas dan kendala lainnya dalam pembelajaran bisa didiskusikan siswa dengan guru melalui grup whatsApp. Dalam pengiriman tugas oleh siswa ke google classroom, siswa memilih pilihan "tugas anda" pada laman akun (yang sudah ditampilkan pada gambar) kemudian akan muncul tampilan Gambar 15. Lalu siswa bisa mengklik "tambahkan lampiran" lalu upload lampiran tugas, maka akan mucul tampilan Gambar 16.

\section{Petunjuk Tugas Siswa \\ Pertumbuhan dan perkembangan \\ 100 poin}

Jawablah pertanyaan berikut dibuku latihan dan kemudian foto dan kirim ke folder ini kembali agar dinilai

Lampiran

IMG-20200805-WA0014.jpg

IMG-20200805-WA0015.jpg

Gambar 14. Tampilan tugas soal dari guru di google classroom.

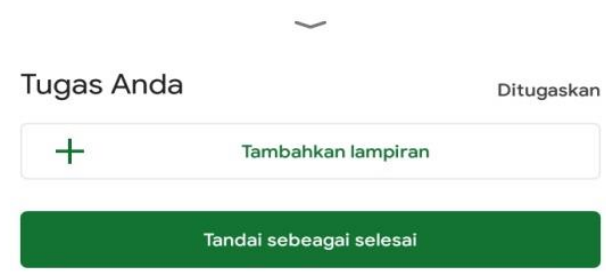

Gambar 15. Tampilan jika siswa ingin mengirim tugas di google classroom.

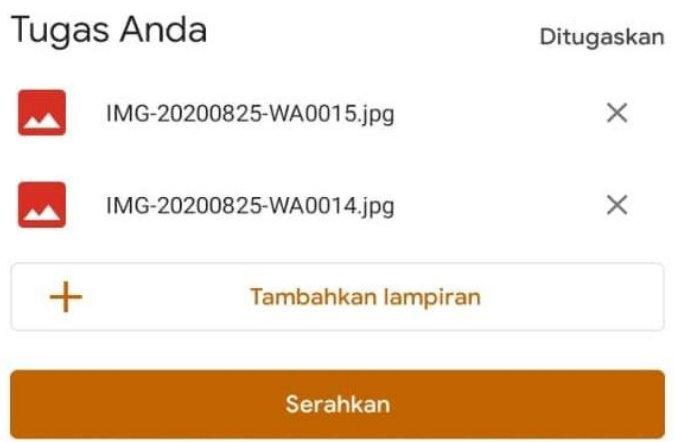

Gambar 16. Tampilan pengiriman tugas oleh siswa di google classroom.

Terakhir klik pada kotak "serahkan" maka tugas sudah diserahkan kepada guru. Setelah siswa mengirimkan tugasnya sesuai pada forum materi maka dalam forum akan terlihat siapa saja yang sudah mengumpulkan (Gambar 17). 
Ismi Fahrunnisah Rambe \& Indayana Febriani Tanjung, Implementasi Pembelajaran Biologi Berbasis Daring pada Masa Pandemi COVID-19 di Madrasah Aliyah Negeri.

Jurnal Biolokus: Jurnal Penelitian Pendidikan Biologi dan Biologi Vol.4(1)

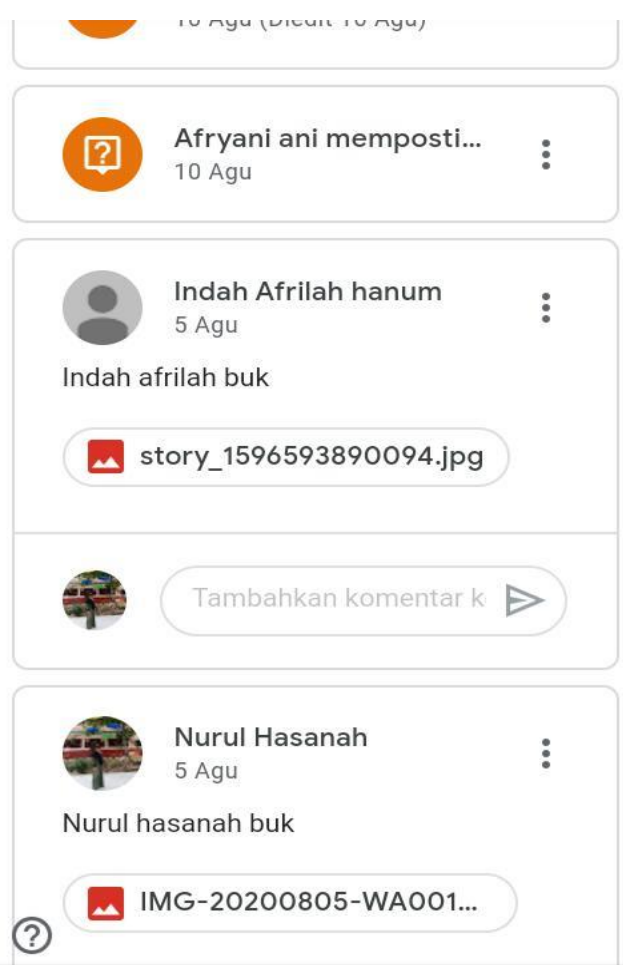

Gambar 17. Tampilan siswa yang sudah mengirim tugas di google classroom.

\section{Penilaian Implementasi Pembelajaran Biologi Berbasis Daring \\ Penilaian pembelajaran pada}

implementasi pembelajaran biologi berbasis daring di MAN 1 Mandailing Natal meliputi dua aspek yaitu penilaian pengetahuan dan penilaian keterampilan (Gambar 18).

09:38 ๑
$\leftarrow$
Tenggat: 18 Sep 08:15
Ulangan harian 2
100 poin
Tambahkan komentar kelas
Pilihlah salah satu jawaban yang paling tepat
Lampiran
PDF Struktur dan Fungsi Jaringan Pada Tumbuhan.pdf

Gambar 18. Tampilan file ujian yang sudah diupload guru di google classroom.

Siswa tinggal membuka file ujian dan mengerjakannya, kemudian jika siswa sudah selesai maka siswa tinggal mengirimkan jawaban ujian dengan cara yang sama seperti pada pengumpulan tugas pembelajaran melalui pilihan "tugas anda" seperti pada gambar diatas. Berikut ini hasil dokumentasi dari soal ujian yang diberikan guru kepada siswa dalam bentuk pilihan ganda (Gambar 19).

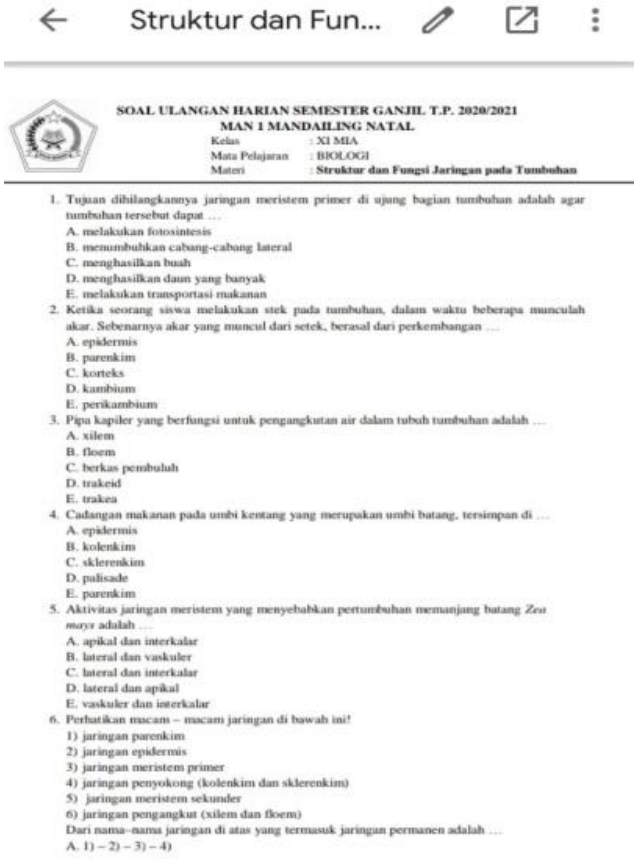

Gambar 19. Tampilan soal ujian yang sudah diupload guru di google classroom.
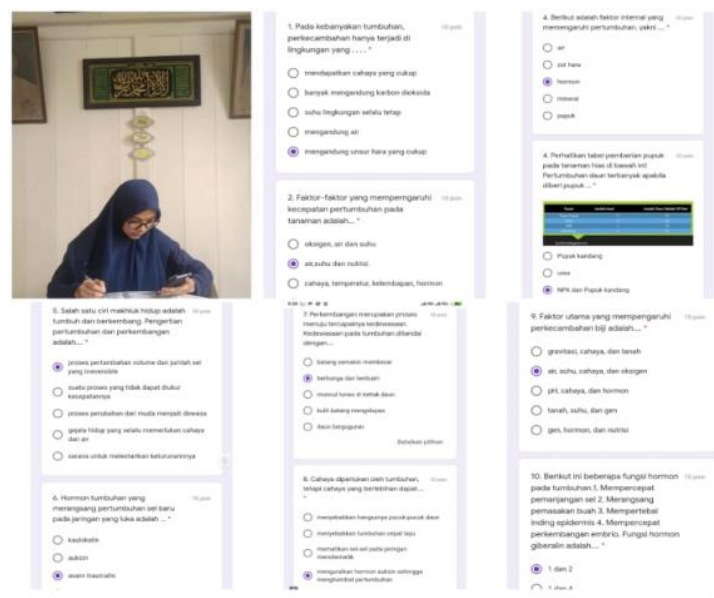

$$
\begin{gathered}
\text { Jum'at, } 14 \text { Agustus } 2020 \\
\text { Ulangan Harian BIOLOGI } \\
\text { Yolanda Aisyah Fitri Siregar } \\
\text { XII MIA } 3
\end{gathered}
$$

Gambar 20. Tampilan ujian siswa di google form.

Berdasarkan pemaparan guru biologi melalui wawancara penilaian pada pembelajaran biologi berbasis daring pada masa pandemi COVID-19 di MAN 1 Mandailing Natal tidak telalu berpatokan terhadap nilai- 
nilai hasil ujian atau soal yang dijawab karena sesuai dengan peraturan pemerintah bahwa pembelajaran pada masa pandemi COVID-19 ini tidak harus memaksakan ketuntasan sesuai kurikulum. Penilaian utama adalah pada kehadiran dan partisipasi siswa selama pembelajaran.

Pada saat ujian siswa harus mengirimkan dokumentasi bukti mengerjakan ujian sendiri. Berikut ini beberapa hasil dokumentasi tampilan ujian siswa melalui google form (Gambar 20). Setelah menjawab soal ujian maka akan muncul hasil dari jawaban siswa sebagaimana Gambar 21.

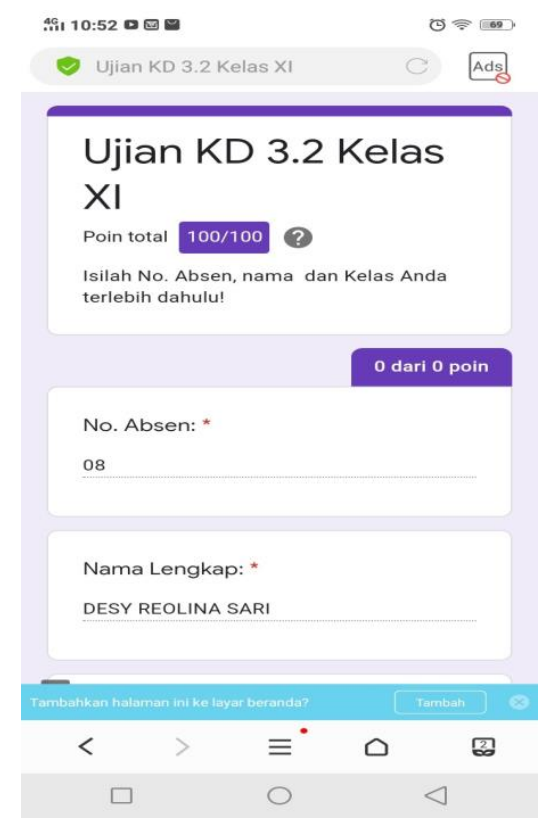

Gambar 21. Tampilan hasil ujian siswa di google form.

Berdasarkan data yang telah didapatkan, implementasi pembelajaran biologi berbasis daring pada masa pandemi COVID-19 di MAN 1 Mandailing Natal dilaksanakan melalui aplikasi google form, google classroom dan whatsApp. Pemilihan aplikasi dilakukan dengan mempertimbangkan kebutuhan dan kemudahan akses bagi guru dan siswa di MAN 1 Mandailing Natal, sehingga proses pembelajaran dapat dilaksanakan dengan lancar. Hal ini sesuai dengan Abidin et al. (2020) yang menyatakan bahwa pemilihan media atau akses media dalam pembelajaran selama pandemi COVID-19 harus disesuaikan dengan keadaan sekolah dan kemampuan guru serta siswa supaya pembelajaran dapat terlaksana. Penggunaan aplikasi berbasis teknologi tersebut memiliki sumbangsih yang besar dalam lembaga pendidikan, termasuk di dalamnya adalah pencapaian tujuan pembelajaran jarak jauh (Korucu \& Alkan, 2011).

Dalam pelaksanaan pembelajaran biologi berbasis daring di MAN 1 Mandailing Natal meliputi beberapa aspek dalam pelaksanaannya yaitu perencanaan pembelajaran, pelaksaksanaan pembelajaran, dan penilaian pembelajaran. Sebagaimana tahapan implementasi dalam Syaifuddin (2016), bahwa dalam proses implementasi setidaknya ada tiga tahapan atau langkah yang harus dilaksanakan, yaitu: tahap perencanaan, tahap pelaksanaan, dan tahap penilaian.

Rencana pelaksanaan pembelajaran (RPP) daring yang dibuat disesuaikan terhadap kondisi dan ketersediaan sarana pembelajaran dengan memastikan kompetensi pembelajaran yang ingin dicapai dan dilarang memaksakan penuntasan kurikulum dan fokus pada pendidikan kecakapan hidup (Kementerian Pendidikan dan Kebudayaan S.E No. 15 Th. 2020). Oleh karena itu, RPP oleh guru biologi dimuat dalam 1 lembar RPP permateri pembelajaran untuk memudahkan dalam pembelajaran secara daring, dan hal ini sudah disesuaikan dengan kondisi media aplikasi yang digunakan oleh guru.

Perencanaan dalam penerapan pembelajaran biologi berbasis daring pada masa pandemi COVID-19 di MAN 1 Mandailing Natal sudah menyesuaikan dengan Surat Edaran Kementerian Pendidikan dan Kebudayaan Nomor 15 tahun 2020, yaitu perencanaan yang dibuat oleh guru biologi tersebut berupa penentuan media aplikasi jarak jauh, memfasilitasi pembelajaran jarak jauh (membuat grup whatsApp perkelas untuk alternatif media komunikasi dan menyiapkan rencana pelaksanaan pembelajaran jarak jauh serta bahan ajar). 


\section{Jurnal Biolokus: Jurnal Penelitian Pendidikan Biologi dan Biologi Vol.4(1)}

Perencanaan pembelajaran biologi berbasis daring di MAN 1 Mandailing Natal dilakukan untuk mengetahui apa saja alat dan bahan serta bagaimana akan dilaksanakan kegiatan pembelajaran. Hal ini sesuai dengan perencanaan pembelajaran daring yang dipaparkan oleh Bilfaqih \& Qomarudin (2015) bahwa "perencanaan pembelajaran daring berisi tentang aturan main, pemilihan aktivitas yang dapat mendukung dalam menjawab pertanyaan esensial dengan cara mengintegrasikan berbagai subyek yang mungkin, serta mengetahui alat dan berbagai bahan yang dapat diakses untuk membantu penyelesaian proyek".

Pelaksanaan pembelajaran biologi berbasis daring yang dilaksanakan oleh guru biologi di MAN 1 Mandailing Natal secara umum sesuai dengan peraturan pelaksanaan yang dibuat oleh pemerintah, namun beberapa hal disesuaikan dengan kondisi di MAN 1 Mandailing Natal yang hal ini juga sesuai dengan Surat Edaran Kementerian Pendidikan dan Kebudayaan Nomor 15 Tahun 2020 Tentang Pedoman Penyelenggaraan Belajar Dari Rumah Dalam Masa Darurat Penyebaran Corona Virus Disease (COVID-19), dimana dipaparkan bahwa "pendidik dalam pelaksanaan pembelajaran jarak jauh memfasilitasi pelaksanaan pembelajaran jarak jauh yang disesuaikan dan telah disepakati bersama sekolaj dan orang tua/wali peserta didik" (Kementerian Pendidikan dan Kebudayaan S.E No. 15 Th. 2020). Tahapan proses pembelajaran biologi berbasis daring umumnya sama dengan tahapan pada proses pembelajaran bisanya yaitu berupa pendahuluan, isi, dan penutup.

Penilaian pembelajaran pada implementasi pembelajaran biologi berbasis daring di MAN 1 Mandailing Natal yaitu penilaian pengetahuan dan keterampilan. Penilaian pengetahuan pada pembelajaran biologi berbasis daring dinilai dari hasil tugas soal-soal yang diberikan, diskusi tanya jawab dan percakapan serta penugasan. Sedangkan penilaian keterampilan pada pembelajaran biologi berbasis daring dinilai dari hasil penugasan proyek berupa video, penilaian produk berupa hasil praktikum yang dilaksanakan siswa di rumah dan tugas menggambar, dan penilaian portofolio melalui penugasan ringkasan materi.

Pelaksanaan pembelajaran biologi berbasis daring di MAN 1 Mandailing Natal dalam persiapan dan pelaksanaan sudah sesuai dengan hal-hal yang ada dalam pembelajaran daring sebagaimana Mustofa et al. (2019) menjelaskan beberapa kegiatan yang harus ada dalam pembelajaran daring, yaitu menyampaikan tujuan belajar, mendorong ingatan kembali, memberi petunjuk belajar, memberikan umpan balik yang informatif. Kegiatan tersebut telah ada dalam kegiatan pembelajaran biologi berbasis daring di MAN 1 Mandailing Natal. Dewi (2020) memaparkan bahwa dampak COVID-19 terhadap implementasi pembelajaran daring di sekolah dapat terlaksana dengan cukup baik apabila adanya kerjasama antara guru, siswa dan orang tua dalam belajar di rumah.

\section{PENUTUP}

Berdasarkan pelaksanaan penelitian di MAN 1 Mandailing Natal dan menganalisis berbagai data temuan, penulis dapat menyimpulkan bahwa dalam proses penerapan pembelajaran biologi berbasis daring meliputi perencanaan, pelaksanaan, dan penilaian pembelajaran. Perencanaan yang dilakukan dalam implementasi pembelajaran biologi berbasis daring di MAN 1 Mandailing Natal yaitu menentukan aplikasi berupa google clasroom, google form, dan whatsApp, pendataan kondisi dan nomor telepon siswa lalu membuat grup whatsApp, menyiapkan rancangan perencanaan pembelajaran (RPP), menyiapkan bahan materi, menentukan media pembelajaran. Kemudian, pelaksanaan yang dilakukan berupa kegiatan pendahuluan, (mengisi absensi melalui google form dan penyampaian tujuan pembelajaran pada google classroom), kegiatan inti (penyampaian materi, sesi tanya jawab dan diskusi), dan kegiatan penutup (penarikan kesimpulan dan 
penugasan). Terakhir, penilaian yang dilakukan berupa penilaian pengetahuan dan penilaian keterampilan. Penilaian pengetahuan dilihat dari hasil tugas soal, diskusi tanya jawab dan percakapan serta penugasan. Penilaian keterampilan dilihat dari hasil penugasan proyek, produk, dan penilaian portofolio.

Dalam hal meningkatkan kualitas dalam implementasi pembelajaran daring, maka perlu adanya tindakan berupa guru membuat rubrik penilaian pembelajaran secara daring sehingga hasil pembelajaran lebih terstruktur dan jelas. Selanjutnya, melaksanakan interaksi langsung dalam pembelajaran daring dengan tatap muka virtual melalui video menggunakan aplikasi yang mudah dipahami guru, misalnya video conference, teleconference, zoom. Kemudian, menyediakan bantuan kuota internet bagi siswa yang membutuhkan oleh pihak sekolah.

\section{REFERENSI}

Abidin, Z., Rumansyah, \& Arizona, K. (2020). Pembelajaran online bebasis proyek salah satu solusi kegiatan belajar mengajar di tengah pandemi COVID-19. Jurnal Ilmiah Profesi Pendidikan, 5(1), 64-70.

Bilfaqih, Y. \& Qomarudin, M.N. (2015). Esensi penyusunan materi pembelajaran daring. Deepublish.

Dewi, W.A.F. (2020). Dampak COVID-19 terhadap implementasi pembelajaran daring di sekolah dasar. Edukatif: Jurnal Ilmu Pendidikan, 2(1), 55-61.

Enriquez, M. A. S. (2014). Students' perceptions on the effectiveness of the use of edmodo as a supplementary tool for learning. DLSU Research Congress, 1-6. https://doi.org/10.1017/CB097811074153 24.004

Handarini, O.I. \& Wulandari, S.S. (2020). Pembelajaran daring sebagai upaya study from home (SFH) selama pandemi COVID-19. Jurnal Pendidikan Administrasi Perkantoran (JPAP), 8(3), 496-503.

He, W., Xu, G., \& Kruck, S. (2014). Online IS Education for the 21st Century . Journal of Information Systems Education, 25(2), 101105.

Iftakhar, S. (2016). Google classroom: What works and how?. Journal of Education and Social Sciences, 3, 12-18.
Korucu, A. T., \& Alkan, A. (2011). Differences between m-learning (mobile learning) and elearning, basic terminology and usage of m-learning in education. Procedia - Social and Behavioral Sciences, 15, 1925-1930. https://doi.org/10.1016/j.sbspro.2011.04.0 29

Majid, A. (2015). Implementasi kurikulum 2013 kajian teoritis dan praktis. Interes Media.

Menteri Pendidikan dan Kebudayaan Republik Indonesia. (2020). Surat Edaran Nomor 4 Tahun 2020 Tentang Pelaksanaan Kebijakan Pendidikan dalam Masa Darurat Penyebaran COVID-19.

Mustofa, M.I., Chodzirin, M., \& Sayekti, L. (2019). Formulasi model perkuliahan daring sebagai upaya menekan disparitas kualitas perguruan tinggi. Walisongo Journal of Information Technology, 1(2), 151-160. http://dx.doi.org/10.21580/wjit.2019.1.2.4 067

Sicat, A. S. (2015). Enhancing college students' proficiency in business writing via schoology. International Journal of Education and Research, 3(1), 159-178.

So, S. (2016). Mobile instant messaging support for teaching and learning in higher education. Internet and Higher Education, 31, 32-42. https://doi.org/10.1016Zj.iheduc.2016.06.0 01

Sugiyono. (2017). Metode penelitian pendidikan (pendekatan kuantitatif, kualitatif, dan $R \& D)$. Alfabeta.

Syahmina, I., Tanjung, I.F., \& Rohani. (2020). Efektivitas pembelajaran biologi pada masa pandemi COVID-19 di madrasah negeri medan. Jurnal Biolokus: Jurnal Penelitian Pendidikan Biologi dan Biologi, 3(2), 320327.

Syaifuddin. (2016). Desain pembelajaran dan implementasinya. Ciputat: PT. Quantum Teaching.

WHO. (n.d.). Points of entry and mass gatherings. Retrieved March 28, 2020, from https://www.who.int/emergencies/disease s/novel-coronavirus-2019/technicalguidance/points-of-entry-and-massgatherings 